\title{
Identification of a Gene Conferring High Levels of Resistance to Verticillium Wilt in Solanum chacoense
}

\author{
D. R. Lynch, L. M. Kawchuk, and J. Hachey, Research Centre, Agriculture and Agri-Food Canada, P. O. Box \\ 3000, Lethbridge, Alberta T1J 4B1; P. S. Bains, Crop Diversification Centre North, Alberta Agriculture, Food and \\ Rural Development, RR 6, 17507 Fort Rd., Edmonton, Alberta T5B 4K3; and R. J. Howard, Crop Diversification \\ Centre South, Alberta Agriculture, Food and Rural Development, SS4, Brooks, Alberta T1R 1E6
}

\begin{abstract}
Lynch, D. R., Kawchuk, L. M., Hachey, J., Bains, P. S., and Howard, R. J. 1997. Identification of a gene conferring high levels of resistance to Verticillium wilt in Solanum chacoense. Plant Dis. 81:1011-1014.

Verticillium wilt (Verticillium albo-atrum) is an important disease affecting potato tuber yield and quality. In North America the major commercial cultivars are susceptible and management strategies for control of the pathogen rely mainly on soil fumigation and crop rotation. In this study 398 genotypes from accessions of Solanum berthaultii, S. chacoense, and S. tarijense were screened for resistance to Verticillium albo-atrum. Resistant genotypes were identified in all but two accessions; however, results indicate that tolerance is more common than resistance. We identified two genotypes in S. chacoense (PI 472819) that had low stem-colonization levels and also did not develop wilt symptoms when inoculated with $V$. albo-atrum. These genotypes and a susceptible genotype from PI 472810 (S. chacoense) were studied to determine genetic inheritance. Segregation ratios in $F_{1}, F_{2}$, and backcross populations indicated that resistance in one of the resistant genotypes (18-21R) was controlled by a single dominant gene. Transfer of the $V_{c}$ gene to tetraploid germ plasm could provide effective and economical control of Verticillium wilt.
\end{abstract}

Verticillium wilt, caused by Verticillium albo-atrum Reinke \& Berthier or Verticillium dahliae Kleb., is a common vascular disease causing severe yield and quality losses in many crops. In a recent survey in North America, Verticillium wilt was ranked as the most important disease of both seed and commercial potato crops, and the second greatest constraint on tuber yield (24). Pathogen-mediated reductions in net photosynthesis, transpiration, and increased leaf temperature (6) cause premature foliage senescence and yield loss. Disease symptoms in potato include wilting and leaf chlorosis and necrosis, while the tubers of infected plants develop necrosis in the vascular tissue that reduces tuber quality, in particular for the manufacture of french fries and chips (24). Abiotic factors such as moisture stress and high temperatures accelerate development of visual symptoms. Studies in Ohio (20) and Wisconsin $(18,19)$ demonstrate a synergistic interaction between root-lesion nematodes (Pratylenchus penetrans (Cobb) Filipjev \&

Corresponding author: D. R. Lynch

E-mail: lynchd@em.agr.ca

LRC Contribution No. 3879657.

Accepted for publication 17 May 1997.

Publication no. D-1997-0627-02R

(C) 1997 Department of Agriculture and Agri-

Food, Government of Canada
Schuur. Stekh.) and Verticillium wilt, further complicating disease control.

Management strategies for the control of the pathogen include soil fumigation, crop rotation (4), and development of resistant cultivars $(8,9)$. While several recent cultivar releases have some resistance to the pathogen, the major potato varieties grown in North America are susceptible. The genetic mechanisms of resistance towards the soil-borne fungi of the taxon Verticillium spp. vary from polygenic in strawberry (27) and alfalfa (28) to a dominant single gene in cotton (3), sunflower (25), and tomato (26). Conclusions from studies with tetraploid Solanum tuberosum subsp. tuberosum L. suggest that inheritance is polygenic and complex $(16,23)$. Screening for resistance in the non-cultivated diploid tuber-bearing wild Solanum species identified resistance but not immunity (8), and a recent study concluded that the resistance is polygenic and genetically complex (7). Thus, incorporation of this resistance into new cultivars is difficult and inefficient.

Research was undertaken to identify resistant clones in plant introductions of the diploid wild species $S$. berthaultii Hawkes, $S$. chacoense Bitter, and S. tarijense Hawkes known to contain resistant genotypes (11). Verticillium wilt-resistant clones were subsequently characterized to determine the level of resistance, host colonization, and genetic inheritance. This study describes identification of the first single gene resistance towards Verticillium wilt in potato.

\section{MATERIALS AND METHODS}

Plant material. Botanical seed of accessions of S. berthaultii (PI 20881, 265857, 265858, 310971, 473331), S. chacoense (PI WRF267, 275141, 471819, 472810, 472819) and $S$. tarijense (PI 195206, $217458,473228,473236)$ reported to contain genotypes resistant to Verticillium wilt, were selected from the inventory maintained by the USDA Potato Introduction Station (Sturgeon Bay, WI; 11), treated with gibberellic acid $\left(\mathrm{GA}_{3} ; 1.5 \mathrm{~g}\right.$ liter $^{-1}$; Sigma-Aldrich Ltd. Ontario, Canada) and planted in seedling flats containing Cornell Mix (5). After 14 days (fourleaf stage), the seedlings were transplanted into Cornell Mix contained in $15-\mathrm{cm}$ plastic pots and placed in a growth chamber (Conviron Ltd., Winnipeg, Canada) with a $22 / 18^{\circ} \mathrm{C}$ day/night temperature regime and a 16-h photoperiod. Tubers were harvested from tuber-bearing genotypes 4 months after transplanting and stored for 4 months at $4^{\circ} \mathrm{C}$. After natural dormancy release, sprouted tubers of a total of 398 genotypes (16 replications per genotype) of the accessions were planted in alternate sleeves in Cornell mix contained in 32-cell rootrainers (Lamaire Industries, Ltd., Edmonton, Canada) and placed in a greenhouse. A rootrainer consists of plastic sleeves which, when folded, form individual cells with the sleeves contained in a plastic tray. In the 32-cell rootrainer, each sleeve forms 4 cells, and there are 8 sleeves per tray. In addition, 8 single 'eyes' from 5 control varieties with established disease reactions were included in the screening trial: susceptible, Russet Norkotah and Shepody; moderately susceptible, Russet Burbank; resistant, A66107-51 and A68113-4 (2,9).

Inoculum preparation and inoculation. An aggressive isolate of $V$. alboatrum, obtained from infected potato plants from Alberta, Canada, was used in the study. Conidia were collected from 10- to 14-day-old cultures grown in potato dextrose broth at room temperature with shaking (100 rpm). Cultures were filtered through cheesecloth and conidia concentrated from the filtrate by centrifugation at $5,000 \times g$ for $25 \mathrm{~min}$ and then diluted with sterile deionized water to give a concentration of approximately $5 \times 10^{7}$ spores $\mathrm{ml}^{-1}$. 
The plants were inoculated with the $V$. albo-atrum spore suspension 4 weeks after planting, using a modification of the procedure described by Huang and Hanna (15). The folding sleeve design of the rootrainer enabled removal of the intact plant from the container. Root injury was accomplished by removing the lower half of the root ball and inoculation by submerging the remaining portion of the root ball for $10 \mathrm{~min}$ in the spore suspension. Four control plants (a single sleeve) in each 32-cell rootrainer were root damaged but not inoculated.

Resistance evaluation. Disease reaction ratings were initiated 4 weeks after inoculation and conducted at weekly intervals for a further 4 weeks to confirm earlier ratings. Genotypes that showed no visual symptoms were rated as resistant (Table 1), while the reactions of susceptible genotypes included wilting, chlorosis, and necrosis of the lower leaves (Fig. 1). All resistant and a few of the susceptible genotypes from all accessions were retained for further study.

Table 1. Resistance to Verticillium albo-atrum in Solanum chacoense, S. tarijense, and S. berthaultii rated by visual foliage reaction ${ }^{\mathrm{z}}$

\begin{tabular}{ccc}
\hline Accession no. & No. of genotypes screened & \% resistant or tolerant \\
\hline S. chacoense & & \\
WRF 267 & 41 & 14.6 \\
PI275141 & 15 & 0.0 \\
PI471819 & 27 & 22.2 \\
PI472810 & 35 & 25.7 \\
PI472819 & 32 & 6.2 \\
S. tarijense & & \\
PI195206 & 33 & 6.1 \\
PI217458 & 11 & 0.0 \\
PI473228 & 20 & 20.0 \\
PI473236 & 40 & 15.0 \\
S. berthaultii & & \\
PI208881 & 15 & 13.3 \\
PI265857 & 45 & 14.0 \\
PI265858 & 22 & 3.0 \\
PI310971 & 46 & 18.0 \\
PI473331 & 16 & 25.0 \\
\hline
\end{tabular}

${ }^{\mathrm{z}}$ Roots damaged and inoculated with a spore suspension.

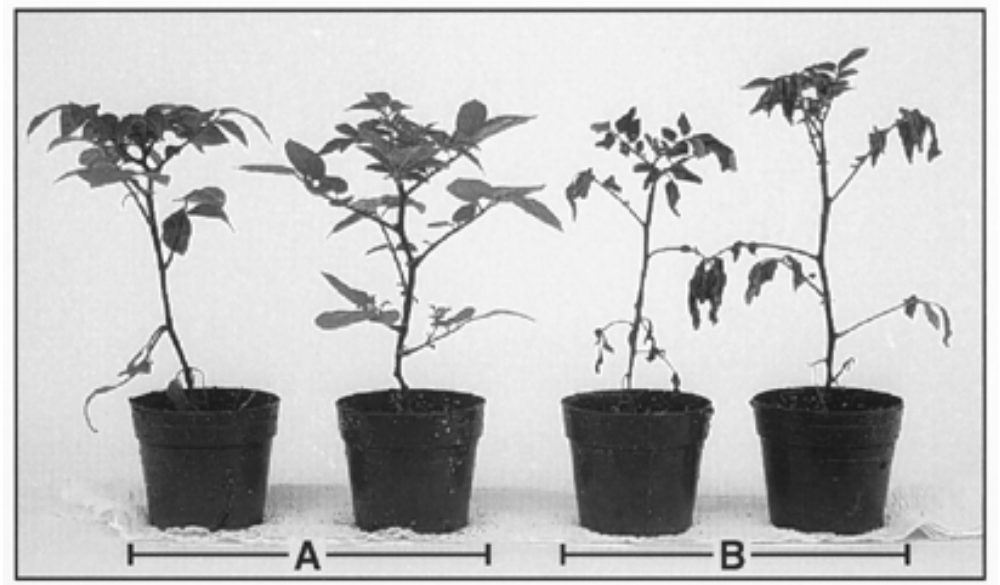

Fig. 1. Foliage reaction to inoculation with Verticillium albo-atrum of resistant (A) and susceptible (B) Solanum chacoense test cross progeny. diffuse light for 10 days. The number of CFU were counted and used to estimate the total CFU in the $0.1-\mathrm{ml}$ aliquot. The result was expressed as $\log _{10}(\mathrm{CFU}+1) / 0.1 \mathrm{ml}$.

Genetic studies. Clones that were rated resistant and with zero or very low CFU as well as susceptible clones were included in genetic studies. Inoculation of these genotypes (Table 2) was repeated to confirm earlier results. Reciprocal crosses were made between resistant and susceptible $S$. chacoense clones and $\mathrm{F}_{1}$ segregating populations derived from these hybridizations screened for resistance. An $\mathrm{F}_{2}$ population was generated by hybridizing resis$\operatorname{tant} F_{1}$ siblings. Selfing was not successful, probably due to gametophytic self-incompatibility associated with S-alleles (13). To confirm our results, resistant $\mathrm{F}_{1}$ hybrids were backcrossed to the susceptible parent. Hybridization, using emasculated plants, was carried out in a growth room (Conviron Ltd.) with a $20 / 18^{\circ} \mathrm{C}$ day/night temperature regime and a 20-h photoperiod. Resistance screening (as previously described) of the segregating populations was carried out in a growth chamber (Conviron Ltd.) with a $22 / 18^{\circ} \mathrm{C}$ day/night temperature regime and $16-\mathrm{h}$ photoperiod. Each rootrainer contained 12 plants inoculated with the pathogen, and 4 control plants that were root-damaged but not inoculated and kept separate from the inoculated plants.

\section{RESULTS}

Resistant genotypes were identified by visual screening in all the accessions sampled, except for S. chacoense PI 275141 and S. tarijense PI 217458 (Table 1). Ratings for the varieties included in the experiment as controls were consistent with published disease reactions $(2,9)$. No wilt symptoms were observed in resistant plants, whereas the disease reaction for susceptible plants included severe wilting, chlorosis and necrosis of the lower leaves, and eventual death of the plant (Fig. 1). Some variation was observed in the severity and occurrence of disease symptoms following inoculation in susceptible plants.

Extensive stem colonization by the pathogen occurred in most of the genotypes visually rated as resistant (Table 2). Two genotypes from $S$. chacoense, designated 18-21R and 18-7R from PI 472819, with low stem colonization levels, 0 and $0.30 \log _{10} \mathrm{CFU} / 0.1 \mathrm{ml}$, respectively, were selected, and reciprocal crosses between these two resistant clones and a highly susceptible genotype designated 12-9S from PI 472810 were made (Table 3). Segregation ratios for the reciprocal hybridizations suggested that the $18-21 \mathrm{R}$ clone was heterozygous resistant and 12-9S homozygous susceptible for a single dominant gene controlling Verticillium wilt resistance, and that inheritance was nuclear (Table 3). Hybridizations with the 18-7R clone produced segregation ratios that 
indicated complex inheritance and did not fit the expected ratio for a one- or twogene model (data not shown).

The result for $18-21 \mathrm{R} \times 12-9 \mathrm{~S}$ was confirmed by crossing a resistant $F_{1}$ hybrid with a sibling resistant $F_{1}$ hybrid (selfing was not successful), and by backcrossing the resistant $F_{1}$ hybrid to the susceptible parent. Segregation ratios for both hybridizations were consistent with the expected ratios for a one-gene model and the dominance of resistance over susceptibility $(P>0.99)$. The proposed designation of the gene $\mathrm{V}_{\mathrm{c}}$ reflects the $S$. chacoense source (Table 3). Our results suggest that inheritance of the resistance is simple, and nuclear.

\section{DISCUSSION}

To our knowledge this is the first study to report single gene resistance towards
Verticillium wilt in potato. Previous genetic studies of resistance towards Verticillium wilt in diploid and tetraploid Solanum species suggest complex polygenic inheritance $(7,23)$. Furthermore, results indicate that tolerance is more common than resistance to Verticillium wilt in the $S$. berthaultii, S. chacoense, and S. tarijense accessions examined.

As reported by others $(8,21)$, visual symptom expression and the magnitude of stem invasion by the pathogen were poorly correlated. This finding supports the distinction between tolerance (no visual symptoms with significant stem invasion) and resistance (no symptoms and very low stem invasion). Tolerance is undesirable because it facilitates proliferation of the pathogen in the soil. Results from this and other studies $(7,23)$ suggest that genetic

Table 2. Stem invasion by Verticillium albo-atrum in asymptomatic genotypes of Solanum chacoense accessions ${ }^{\mathrm{w}}$

\begin{tabular}{|c|c|c|}
\hline Accession no. & Clone no. & $\mathrm{CFU}^{\mathrm{x}} \log _{10}(\mathrm{CFU}+1) / 0.1 \mathrm{ml}$ \\
\hline \multirow[t]{6}{*}{ WRF 267} & 7 & $2.40 \pm 0.90$ \\
\hline & 10 & $>2.45$ \\
\hline & 25 & $0.60 \pm 0.49$ \\
\hline & 30 & $2.06 \pm 1.22$ \\
\hline & 33 & $>2.45$ \\
\hline & 34 & $>2.45$ \\
\hline \multirow[t]{9}{*}{ PI472810 } & 3 & $1.99 \pm 1.66$ \\
\hline & 12 & $0.76 \pm 0.29$ \\
\hline & 14 & $1.49 \pm 0.78$ \\
\hline & 20 & $>2.45$ \\
\hline & 27 & $>2.45$ \\
\hline & 31 & $1.54 \pm 0.50$ \\
\hline & 33 & $1.54 \pm 1.31$ \\
\hline & 36 & $1.85 \pm 1.43$ \\
\hline & 52 & $2.20 \pm 1.25$ \\
\hline \multirow[t]{6}{*}{ PI471819 } & 2 & $2.34 \pm 1.92$ \\
\hline & 5 & $1.00 \pm 0.74$ \\
\hline & 9 & $1.52 \pm 0.84$ \\
\hline & 10 & $1.98 \pm 1.59$ \\
\hline & 12 & $1.86 \pm 0.70$ \\
\hline & 23 & $1.83 \pm 1.78$ \\
\hline \multirow[t]{2}{*}{ PI472819 } & 7 & $0.30 \pm 0.21^{\mathrm{y}}$ \\
\hline & 21 & $0.00^{\mathrm{z}}$ \\
\hline
\end{tabular}

${ }^{\text {w }}$ Root-damaged plants inoculated with a spore suspension.

${ }^{\mathrm{x}}$ Mean of 15 stems.

${ }^{y}$ Resistant parent (18-7R).

${ }^{\mathrm{z}}$ Resistant parent (18-21R).

Table 3. Segregation for Verticillium wilt resistance in crosses of Solanum chacoense clones from PI 472819 and 472810

\begin{tabular}{|c|c|c|c|c|c|c|c|c|c|}
\hline \multirow[b]{3}{*}{ Materials } & \multirow[b]{3}{*}{ No. of plants tested } & \multicolumn{4}{|c|}{ Disease reaction } & \multirow[b]{3}{*}{$\chi^{2}$} & \multirow[b]{3}{*}{$P^{z}$} & \multirow[b]{3}{*}{ Postulated genotypes } & \multirow{3}{*}{$\begin{array}{l}\text { Phenotypic ratio } \\
\text { resistant:susceptible }\end{array}$} \\
\hline & & \multicolumn{2}{|c|}{ Observed } & \multicolumn{2}{|c|}{ Expected } & & & & \\
\hline & & $\mathbf{R}^{\mathbf{y}}$ & $\mathbf{S}^{\mathbf{y}}$ & $\mathbf{R}$ & $\mathbf{S}$ & & & & \\
\hline \multicolumn{10}{|l|}{ Parents } \\
\hline 18-21R (PI472819) & 60 & 60 & 0 & $\ldots$ & $\ldots$ & $\ldots$ & $\ldots$ & $\mathrm{V}_{c} \mathrm{v}_{c}$ & \\
\hline 12-9S (PI472810) & 54 & 0 & 54 & $\ldots$ & $\ldots$ & $\ldots$ & $\ldots$ & $v_{c} v_{c}$ & \\
\hline \multicolumn{10}{|l|}{$\mathrm{F}_{1}$ generation } \\
\hline $18-21 \mathrm{R} \times 12-9 \mathrm{~S}$ & 52 & 32 & 20 & 26 & 26 & 2.77 & 0.10 & $\mathrm{~V}_{\mathrm{c}} \mathrm{v}_{\mathrm{c}}, \mathrm{v}_{\mathrm{c}} \mathrm{v}_{\mathrm{c}}$ & $1: 1$ \\
\hline $12-9 \mathrm{~S} \times 18-21 \mathrm{R}$ & 176 & 86 & 90 & 88 & 88 & 0.09 & $0.75-0.90$ & $\mathrm{~V}_{\mathrm{c}} \mathrm{v}_{\mathrm{c}}, \mathrm{v}_{\mathrm{c}} \mathrm{v}_{\mathrm{c}}$ & $1: 1$ \\
\hline \multicolumn{10}{|l|}{$\mathrm{F}_{2}$ generation } \\
\hline $\begin{array}{l}\mathrm{F}_{1} \text {-resistant hybrid } \times \\
\mathrm{F}_{1} \text {-resistant hybrid }\end{array}$ & 80 & 60 & 20 & 60 & 20 & 0.00 & $>0.99$ & $\mathrm{~V}_{\mathrm{c}} \mathrm{V}_{\mathrm{c}}, \mathrm{V}_{\mathrm{c}} \mathrm{v}_{\mathrm{c}}, \mathrm{v}_{\mathrm{c}} \mathrm{v}_{\mathrm{c}}$ & $3: 1$ \\
\hline $\begin{array}{l}\text { Backcross generation } \\
12-9 \mathrm{~S} \times \\
\mathrm{F}_{1} \text {-resistant hybrid }\end{array}$ & 117 & 58 & 59 & 58 & 59 & 0.00 & $>0.99$ & $\mathrm{~V}_{\mathrm{c}} \mathrm{v}_{\mathrm{c}}, \mathrm{v}_{\mathrm{c}} \mathrm{v}_{\mathrm{c}}$ & $1: 1$ \\
\hline
\end{tabular}

${ }^{y} \mathrm{R}=$ resistant, $\mathrm{S}$ = susceptible; assessed by inoculating the plants with a spore suspension of Verticillium albo-atrum and rating visual wilt symptoms.

${ }^{\mathrm{z}}$ Probability of $\chi^{2} \leq$ the calculated value. 
NRSP-6 collection (Sturgeon Bay, WI) with a dominant resistance gene for Verticillium wilt $\mathrm{V}_{\mathrm{c}}$ in a diploid wild species of potato. Transfer of the gene to tetraploid germ plasm and the development of resistant commercial varieties should provide effective and economical control of Verticillium wilt.

\section{ACKNOWLEDGMENTS}

Funding received from the Alberta Agricultural Research Institute, Farming for the Future (Project 920117) is gratefully acknowledged. The wild Solanum species used in the study were provided by the Potato Introduction Station, NRSP-6, Sturgeon Bay, WI, and the dihaploids by H. De Jong, Agriculture and Agri-Food Canada, Fredericton Research Centre, New Brunswick. We thank Carol Mueller for excellent technical assistance.

\section{LITERATURE CITED}

1. Alexander, L. J. 1962. Susceptibility of certain Verticillium resistant tomato varieties to an Ohio isolate of the pathogen. Phytopathology 52:998-1000.

2. Anderson, N., and Hoyos, G. 1987. Varietal responses of potato to Verticillium wilt. Valley Potato Grower 53(105):10-14.

3. Barrow, J. R. 1970. Heterozygosity in inheritance of Verticillium wilt tolerance in cotton. Phytopathology 60:301-303.

4. Ben-Yephet, Y., Frank, Z. R., MaleroVera, J. M., and DeVay, J. E. 1989. Effect of crop rotation and metham-sodium on Verticillium dahliae. Pages 543-556 in: Vascular Wilt Diseases of Plants: Basic Studies and Control, Vol. 28. Springer-Verlag, New York.

5. Boodley, J. W., and Sheldrake, R. 1977. Cornell peat-lite mixes for commercial plant growing. Cornell Univ. Coop. Ext. Div. Info. Bull. 43.

6. Bowden, R. L., and Rouse, D. I. 1991. Effects of Verticillium dahliae on gas exchange of potato. Phytopathology 81:293-301.

7. Concibido, V. C., Secor, G. A., and Jansky, S.
H. 1994. Evaluation of resistance to Verticillium wilt in diploid, wild potato interspecific hybrids. Euphytica 76:145-152

8. Corsini, D. L., Pavek, J. J., and Davis, J. R. 1988. Verticillium wilt resistance in noncultivated tuber-bearing Solanum species. Plant Dis. 72:148-151.

9. Corsini, D. L., Pavek, J. J., and Davis, J. R. 1990. Verticillium wilt resistant potato germplasm A66107-51 and A68113-4. Am. Potato J. 67:517-525.

10. Dobinson, K. F., Tenuta, G. K., and Lazarovits, G. 1996. Occurrence of race 2 of Verticillium dahliae in processing tomato fields in southwestern Ontario. Can. J. Plant Pathol. 18:55-58.

11. Hanneman, R. E., and Bamberg, J. B. 1986. Inventory of tuber-bearing Solanum species. Bulletin 533. Research Division, College of Agriculture and Life Sciences, University of Wisconsin, Madison.

12. Hermundstad, S. A., and Peloquin, S. J. 1987. Breeding at the $2 \mathrm{X}$ level and sexual polyploidization. Pages 197-210 in: The Production of New Potato Varieties: Technological Advances. Cambridge University Press, Cambridge.

13. Howard, H. W. 1970. Genetics of the Potato. Logos Press Ltd., Wellingborough, England.

14. Hoyos, G. P., Zambino, P. J., and Anderson, N. A. 1991. An assay to quantify vascular colonization of potato by Verticillium dahliae. Am Potato J. 68:727-742.

15. Huang, H. C., and Hanna, M. R. 1991. An efficient method to evaluate alfalfa cultivars for resistance to Verticillium wilt. Can. J. Plant Sci. 71:871-875.

16. Hunter, D. E., Darling, H. M., Stevenson, F. J., and Cunningham, C. E. 1968. Inheritance of resistance to Verticillium wilt in Wisconsin. Am Potato J. 45:72-78

17. Kawchuk, L. M., Lynch, D. R., Hachey, J., Bains, P. S., and Kulcsar, F. 1994. Identification of a codominant amplified polymorphic DNA marker linked to the Verticillium wilt resistance gene in tomato. Theor. Appl. Genet. 89:661-664
18. Kotcon, J. B., Rouse, D. I., and Mitchell, J. E. 1985. Interactions of Verticillium dahliae, Colletotrichum coccodes, Rhizoctonia solani, and Pratylenchus penetrans in the early dying syndrome of Russet Burbank potatoes. Phytopathology 75:68-74.

19. MacGuidwin, A. E., and Rouse, D. I. 1990. Role of Pratylenchus penetrans in the potato early dying disease of Russet Burbank potato. Phytopathology 80:1077-1082.

20. Martin, M. J., Riedel, R. M., and Rowe, R. C. 1982. Verticillium dahliae and Pratylenchus penetrans: Interactions in the early dying complex of potato in Ohio. Phytopathology 72:640-44.

21. Mohan, S. K., Davis, J. R., Corsini, D. L., Sorensen, L. H., and Pavek, J. J. 1990. Reaction of potato clones and accessions of Solanum spp. to Verticillium dahliae Kleb. and its toxin. Potato Res. 33:449-458.

22. Nadakavukaren, M. J., and Homer, C. E 1959. An alcohol agar medium selective for determining Verticillium microsclerotia in soil. Phytopathology 49:527-528.

23. Pavek, J. J., and Corsini, D. L. 1994. Pages 403-409 in: Inheritance of Resistance to Warm-growing-season Fungal Diseases. J. E. Bradshaw and G. R. Mackay, eds. Potato Gen $\mathrm{CAB}$ International, Wallingford, United Kingdom.

24. Powelson, M. L., and Rowe, R. C. 1993. Biology and management of early dying of potatoes. Annu. Rev. Phytopathol. 31:111 126.

25. Putt, E. D. 1964. Breeding behavior of resistance to leaf mottle or Verticillium in sunflowers. Crop Sci. 4:177-179.

26. Schaible, L., Cannon, O. S., and Waddoups, V. 1951. Inheritance of resistance to Verticillium wilt in a tomato cross. Phytopathology 41:986-990.

27. Wilhelm, S. 1955. Verticillium wilt of strawberry with special reference to resistance. Phytopathology 45:387-391.

28. Zaleski, A. 1957. Reactions of lucerne strains to Verticillium wilt. Plant Pathol. 6:137-142. 